\title{
Pengaruh Perputaran Kas dan Perputaran Piutang serta Jumlah Nasabah Terhadap Return On Assets pada Lembaga Perkreditan Desa di Kecamatan Kubu
}

\author{
I Kadek Susena Atmaja Jaya ${ }^{1 *}$, Wayan Cipta ${ }^{2}$ iD \\ ${ }^{12}$ Program Studi Manajemen, Jurusan Manajemen, Universitas Pendidikan Ganesha, Singaraja, Indonesia \\ *ikadeksusenaatmajajaya08@undiksha.ac.id ${ }^{1 *}$
}

\section{Abstrak}

Penelitian ini bertujuan untuk menguji pengaruh tingkat perputaran kas dan perputaran piutang serta jumlah nasabah kredit terhadap return on assets. Desain penelitian ini adalah kuantitatif kausal. Subjek penelitian ini adalah LPD Kecamatan Kubu Tahun 2019 dengan jumlah populasi sebanyak 30 LPD. Data di kumpulkan dengan pencatatan dokumen dan di analisis dengan analisis regresi linier berganda. Hasil penelitian ini menunjukkan bahwa (1) tingkat perputaran kas, perputaran piutang dan jumlah nasabah kredit secara simultan berpengaruh terhadap return on assets, (2) tingkat perputaran kas berpengaruh positif dan signifikan Terhadap return on assets, (3) perputaran piutang berpengaruh positif dan signifikan terhadap return on assets, (4) jumlah nasabah kredit berpengaruh positif dan signifikan terhadap return on assets.

Kata Kunci : kas, nasabah kredit, piutang, return on assets

\section{Abstract}

This study aims to examine the effect of cash turnover and accounts receivable turnover and the total of credit customers on return on assets. The design of this research is quantitative causal. The subject of this research was the LPD in Kubu District in 2019 with a population of 30 LPDs. The data were collected by document recording and analysed by multiple linear regression analysis. The results of this study indicate that (1) the level of cash turnover, accounts receivable turnover and the total of credit customers simultaneously effect to return on assets, (2) the rate of cash turnover has a positive and significant effect to return on assets, (3) accounts receivable turnover has a positive and significant effect to return on assets, (4) the total of credit customers has a positive and significant effect to return on assets.

Keywords: cash turnover, credit customers, accounts receivable turnove, return on assets

\section{Pendahuluan}

Pembangunan perekonomian Indonesia khususnya pada masyarakat pedesaan sangat penting dilakukan dalam menunjang pemerataan pembangunan nasional. Salah satu lembaga organisasi sosial yang diharapkan mampu meningkatkan perekonomian adalah lembaga keuangan. Lembaga keuangan merupakan suatu badan yang kegiatannya menarik dana dari masyarakat dan meyalurkannya kembali ke masyarakat. Kinerja suatu lembaga keuangan dapat dilihat dari Return On Assets (ROA). salah satu lembaga keuangan yang ada di Bali yaitu Lembaga Perkreditan Desa (LPD). Berdasarkan Peraturan Daerah (Perda) Provinsi Bali Nomor 3 Tahun 2007 menyatakan, bahwa LPD merupakan suatu badan keuangan dimana ruang lingkup kegiatan usahanya di lingkungan desa dan diperuntukan bagi krama (warga) desa. LPD menggunakan Peraturan Daerah (PERDA) Provinsi Bali No. 2 tahun

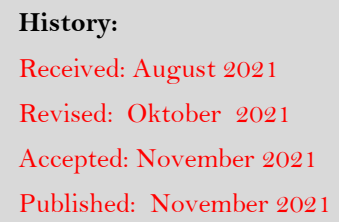

History:

Received: August 2021

Revised: Oktober 2021

Accepted: November 2021

Published: November 2021

Publisher: Undiksha Press

Licensed: This work is licensed under

a Creative Commons Attribution 3.0 License

(c) (i) (?) 
1998, sedangkan bank menggunakan Undang-undang No. 7 tahun 1992 tentang perbankan sebagai dasar hukumnya.

Surata (2011) menyatakan bahwa LPD memiliki beberapa tujuan yaitu : (1) untuk mendorong pembangunan ekonomi masyarakat desa melalui tabungan yang terarah serta penyaluran modal yang efektif, (2) memberantas sistem ijon dan gadai gelap di daerah pedesaan, (3) dapat menciptakan pemerataan dan kesempatan kerja bagi warga pedesaan, (4) serta menciptakan daya beli dan melancarkan lalu lintas pembayaran dan pertukaran di Desa. Peran lainnya dari LPD yang tidak kalah penting adalah kemampuan dalam menghasilkan laba yang menjadi sumber pembiayaan pembangunan desa adat. Tugas dan usaha LPD diarahkan untuk meningkatkan taraf hidup kelompok masyarakat pedesaan. LPD dapat berkembang dengan baik apabila semua aspek - aspek pendukung yang ada di dalamnya mendapat perhatian yang baik dari manajemen, termasuk salah satunya adalah bagaimana proses LPD tersebut dalam memperoleh laba. Besar kecilnya laba yang diperoleh suatu LPD tidak lepas dari kemampuan manajemen mengelola aktiva dan utang yang ada (Rustina, 2003).

Hery (2015) menyatakan, rasio - rasio yang dapat digunakan untuk menilai profitabilitas antara lain yaitu Return On Assets (ROA), Return On Equity (ROE), Gross Profit Margin (GPM), Operaratng Profit Margin (OPM), Net profit margin (NPM). Namun, rasio yang digunakan dalam penelitian ini adalah Return On Assets (ROA). Return On Asset (ROA) merupakan rasio yang menunjukkan hasil (return) atas jumlah aktiva yang digunakan dalam perusahaan. Semakin besar rasio ini semakin baik, karena berarti semakin besar kemampuan perusahaan dalam menghasilkan laba

Pratama (2019) menyatakan Profitabilitas (ROA) dipengaruhi oleh tingkat perputaran kas, perputaran piutang dan jumlah nasabah kredit. Utami, dkk (2019) menyatakan Profitabilitas (ROA) dipengaruhi oleh perputaran kas, ukuran perusahaan dan komposisi pendanaan sedangkan Nopiana, dkk (2015) menyatakan, faktor yang mempengaruhi Profitabilitas (ROA) adalah tingkat perputaran modal kerja, perputaran kas, perputaran piutang, pertumbuhan nasabah, dan jumlah karyawan. Jadi dapat disimpulkan variabel variabel yang mempengaruhi ROA adalah tingkat perputran kas, perputaran piutang, perputaran persediaan, jumlah nasabah kredit, ukuran perusahaan, komposisi pendanaan, perputaran modal kerja, pertumbuhan nasabah dan jumlah karyawan. Penelitian ini lebih memfokuskan menggunakan variabel tingkat perputaran kas, perputaran piutang dan jumlah nasabah kredit yang mempengaruhi ROA. Karena, berdasarkan teori Mulyadi (2005) menyatakan, apabila tingkat perputaran kasnya semakin meningkat, tingkat perputaran piutangnya juga semakin tinggi dan jumlah nasabah kreditnya terus bertambah, maka akan berbanding lurus dengan ROA pada perusahaan tersebut. Pernyataan tersebut di dukung juga teori oleh Kasmir (2005) menyatakan, jika semakin tinggi perputaran kas, perputaran piutang dan jumlah nasabah kredit yang terus meningkat maka akan meningkatkan keuntungan dari perusahaan tersebut.

Tingkat perputaran kas dapat mempengaruhi ROA dari suatu LPD. Kas sebagai unsur modal kerja dengan tingkat likuiditas yang paling tinggi. Secara teoretis praktik perputaran kas merupakan perbandingan jumlah penjualan di mana jumlah penjualan yang dalam lembaga perbankan adalah total pendapatan dengan jumlah kas rata-rata (Riyanto, 2011). Efisiensi penggunaan kas di dalam perusahaan dicerminkan dari jumlah kas yang terdapat dalam perusahaan dan bagaimana kas tersebut berputar pada saat diinvestasikan. Semakin tinggi perputaran kas, dapat menunjukkan peningkatan efisiensi penggunaan kas tersebut dan dapat meningkatkan ROA dari LPD. Pernyataan ini didukung oleh penelitian yang dilakukan Putra dan Wirjaya (2013) pada LPD di Kecamatan Ubud, di mana tingkat perputaran kas berpengaruh positif terhadap profitabilitas (ROA). 
Tingkat perputaran piutang dapat mempengaruhi ROA suatu LPD. Perputaran piutang merupakan proses penerimaan piutang dari suatu perusahaan selama periode tertentu. Piutang dalam suatu perusahaan akan terus berputar. Perputaran piutang yang terjadi dapat menunjukkan berapa kali piutang timbul sampai piutang tersebut dapat tertagih dan dapat dikembalikan ke kas perusahaan tersebut. Semakin besar proporsi piutang dari penyaluran kredit yang dilakukan maka akan diikuti dengan peningkatan laba, sehingga akan meningkatkan ROA (Wild dan Halsey, 2007). Pernyataan ini didukung oleh penelitian yang dilakukan Putra dan Wirjaya (2013) Pada LPD Kecamatan Ubud, dimana tingkat perputaran piutang mempunyai pengaruh positif terhadap profitabilitas (ROA).

Jumlah nasabah dapat mempengaruhi ROA dalam LPD. Nasabah adalah sumber pendapatan utama dalam LPD, yang dimana pendapatan itu diperoleh dari transaksi yang dilakukan oleh nasabahnya. Nasabah LPD dapat dibagi menjadi dua yaitu nasabah kredit dan nasabah penyimpanan. Dalam penelitian ini lebih memfokuskan meneliti jumlah nasabah kreditnya.

Berdasarkan data laporan keuangan LPD Kecamatan Kubu Tahun 2018-2019 ditemukan beberapa permasalahan yaitu Tingkat perputaran kas pada LPD Beluhu tahun 2018 sebesar 4,41 tahun 2019 mengalami peningkatan sebesar 6,57. LPD Tianyar tahun 2018 memiliki tingkat perputaran kas sebesar 2,42, tahun 2019 mengalami peningkatan sebesar 2,85. LPD Tigaron tahun 2018 memiliki tingkat perputaran kas sebesar 4,73, tahun 2019 mengalami penurunan sebesar 4,12. Sehingga dapat disimpulkan bahwa terjadi fluktuasi yang sangat tinggi dari tingkat perputaran kas pada LPD tersebut. Namun, dalam dua tahun tersebut ROA terus mengalami penurunan yang sangat signifikan.

Perputaran piutang pada LPD Beluhu tahun 2018 sebesar 1,40 kali, tahun 2019 mengalami penurunan sebesar 1,38 kali. LPD Tianyar tahun 2018 memiliki perputaran piutang sebesar 1,22 kali, tahun 2019 mengalami peningkatan sebesar 1,48 kali. LPD Tigaron tahun 2018 memiliki perputaran piutang sebesar 1,15 kali dan tahun 2019 mengalami peningkatan sebesar 1,24. Sehingga dapat disimpulkan bahwa terjadi fluktuasi yang tinggi dari perputaran piutang pada LPD tersebut. Namun, dalam tiga tahun tersebut ROA terus mengalami penurunan yang sangat signifikan.

Jumlah nasabah kredit pada LPD Beluhu tahun 2018 sebanyak 588, tahun 2019 mengalami penurunan sebanyak 572. LPD Tianyar tahun 2018 memiliki jumlah nasabah kredit sebanyak 764, tahun 2019 mengalami peningkatan sebanyak 804. LPD Tigaron tahun 2018 memiliki jumlah nasabah kredit sebanyak 813, tahun 2019 mengalami peningkatan sebanyak 844. Sehingga dapat disimpulkan bahwa terjadi fluktuasi yang sangat tinggi dari jumlah nasabah kredit pada LPD tersebut. Namun, dalam dua tahun tersebut ROA terus mengalami penurunan yang sangat signifikan.

Berdasarkan hal tersebut terjadi kesenjangan antara teori dengan fakta masalah yang ada dilapangan. Mulyadi (2005) menyatakan bahwa tingkat perputaran kas semakin meningkat, maka tingkat perputaran piutang juga semakin tinggi dan jumlah nasabah kreditnya terus bertambah, sehingga akan berbanding lurus dengan ROA pada perusahaan tersebut. Menurut Kasmir (2005) jika semakin tinggi perputaran kas, perputaran piutang dan jumlah nasabah yang terus meningkat maka akan meningkatkan keuntungan dari LPD tersebut. Apabila ROA menurun setiap tahunnya dapat dikatakan bahwa lembaga keuangan tersebut dalam kondisi kurang baik. sehingga akan mempengaruhi terhadap kemajuan dan perkembangan LPD tersebut 
Hubungan Tingkat Perputaran Kas, Perputaran Piutang dan Jumlah Nasabah Kredit terhadap ROA

Tingkat perputaran kas dan perputaran piutang digunakan untuk menilai kemampuan LPD dalam mengelola kas dan piutang secara efisien. Tingkat perputaran kas menunjukkan kecepatan perubahan kembali aktiva lancar menjadi kas melalui penjualan. Tingkat perputaran piutang menunjukkan kecepatan pelunasan piutang menjadi kas kembali. Sementara jumlah nasabah kredit juga berperan penting dalam dalam meningkatkan laba suatu LPD karena apabila dalam suatu LPD jumlah nasabahnya meningkat maka akan memperoleh keuntungan yang meningkat pula. Keuntungan tersebut diperoleh dari bunga pinjaman yang diberikan oleh nasabah kredit. Pertumbuhan jumlah nasabah kredit akan berpengaruh pada ROA dari LPD tersebut. Dalam menjalankan kegiatan usahanya LPD hampir sama seperti pengelolaan perbankan sehingga faktor - faktor yang mempengaruhi perekonomian LPD sama dengan lembaga perbankan. Faktor - faktor yang dapat mempengaruhi ROA dari LPD dalam periode tertentu yaitu tingkat perputaran kas, perputaran piutang yang dimiliki, dan jumlah nasabah kredit LPD tersebut. Hal ini sejalan dengan teori Mulyadi (2005) menyatakan, apabila tingkat perputaran kasnya semakin meningkat, tingkat perputaran piutangnya juga semakin tinggi dan jumlah nasabah kreditnya terus bertambah, maka akan berbanding lurus dengan ROA pada perusahaan tersebut. Pernyataan tersebut didukung juga teori oleh Kasmir (2005) yang menyatakan, jika semakin tinggi perputaran kas, perputaran piutang dan jumlah nasabah yang terus meningkat maka akan meningkatkan keuntungan dari perusahaan tersebut. Pernyataan ini juga didukung oleh peneliatan yang dilakukan Putra dan Wirajaya (2013), bahwa tingkat perputaran kas dan perputaran piuang serta jumlah nasabah kredit berpengaruh positif terhadap profitabilitas (ROA) di Kecamatan Ubud.

\section{Hubungan Tingkat Perputaran Kas terhadap ROA}

Perputaran kas (cash turnover) adalah beberapa kali uang kas berputar dalam suatu tertentu melalui penjualan. Dengan menghitung perputaran kas akan diketahui sampai berapa jauh tingkat efisiensi yang dapat dicapai perusahaan dalam upaya mendayagunakan persediaan kas yang ada untuk mewujudkan tujuan perusahaan. Perputaran kas yang semakin tinggi akan semakin membaik, karena menunjukkan semakin efisiensi dalam penggunaan kas. Apabila perputaran kas yang berlebihan, Sedangkan modal kerja yang tersedia terlalu kecil, Sehingga akan kurang cukup untuk memenuhi kebutuhan perusahaan. Demikian pula sebaliknya, dengan makin rendahnya perputaran kas mengakibatkan banyaknya uang kas yang tidak produktif sehingga akan mengurangi ROA perusahaan. Kasmir (2012) menyatakan, rasio perputaran kas yaitu rasio yang berfungsi untuk mengukur tingkat kecukupan modal kerja perusahaan yang dibutuhkan untuk membayar tagihan dan membiayai penjualan. jika rasio perputaran ini tinggi perusahaan akan mampu mengelola kasnya maka akan mampu membayar kewajibannya. Pernyataan ini didukung oleh penelitian yang dilakukan oleh Friskayanti dkk (2014), dimana tingkat perputaran kas berpengaruh positif dan signifikan terhadap profitabilitas (ROA). Hal ini berarti apabila tingkat perputaran kas meningkat, maka ROA yang diterima oleh LPD juga akan meningkat. Namun sebaliknya, apabila tingkat perputaran kas menurun, maka ROA LPD juga akan menurun.

\section{Hubungan Tingkat Perputaran Piutang terhadap ROA}

Piutang terjadi karena adanya penjualan secara kredit. Pemberian kredit kepada pembeli barang atau jasa umumnya dilakukan untuk memperbesar penjualan. Peningkatan penjualan dapat meningkatkan ROA perusahaan. Tapi disisi lain, peningkatan piutang juga membutuhkan tambahan pembiayaan, biaya untuk analisis kredit dan penagihan piutang, serta kemungkinan piutang yang macet tak dapat tertagih. Tinggi rendahnya receivable 
turnover mempunyai efek yang langsung terhadap besar kecilnya modal yang diinvestasikan dalam piutang. Makin tinggi turnover, berarti makin cepat perputarannya, yang berarti makin pendek waktu terikatnya modal dalam piutang, sehingga mempertahankan penjualan bersih tertentu, dengan naiknya turnover, dibutuhkan jumlah modal yang lebih kecil yang diinvestasikan dalam piutang. Menurut Munawir (2004), semakin tinggi rasio piutang (turn over) menunjukkan modal yang tertanam dalam piutang semakin rendah, sebalikanya kalau rasio semakin rendah berarti ada over investment dalam piutang sehingga memerlukan analisis lebih lanjut, mungkin karena bagian kredit dan penagihan bekerja tidak efektif atau mungkin ada perubahan dalam kebijakan pemberian kredit. Pernyataan ini didukung oleh penelitian yang dilakukan oleh Friskayanti dkk (2014), bahwa tingkat perputaran piutang bepengaruh positif dan signifikan terhadap profitabilitas (ROA).

\section{Hubungan Jumlah Nasabah Kredit Terhadap ROA}

Secara logika dapat kita ketahui apabila dalam suatu LPD jumlah nasabahnya meningkat maka akan memperoleh keuntungan yang meningkat. Keuntungan tersebut diperoleh dari bunga pinjaman yang diberikan kepada nasabah kredit. Jumlah nasabah kredit akan berpengaruh pada tingkat ROA suatu LPD tersebut. Pernyataan tersebut didukung juga oleh Riyanto (2001) menyatakan, meningkatnya jumlah nasabah memberikan laba yang cukup besar pada pertumbuhan LPD. Semakin banyak jumlah nasabah yang dimiliki oleh LPD, maka semakin besar pula kesempatan untuk memperbesar laba LPD. Hal itu di karenakan nasabah merupakan peran penting dalam menjaga kelangsungan usaha LPD dalam mencari keuntungan. Pernyataan ini didukung oleh penelitian yang dilakukan oleh Dewi dan Ratnadi (2018), dimana tingkat jumlah nasabah kredit berpengaruh positif terhadap profitabilitas (ROA).

\section{Metode}

Penelitian ini menggunakan desain kuantitatif kausal yang artinya suatu penelitian yang menggambarkan generalisasi atau menjelaskan hubungan sebab -akibat dari dua atau beberapa variabel. Sugiyono (2012) menyatakan, desain kausal adalah hubungan yang bersifat sebab akibat. Jadi disini ada variabel independen (variabel yang mempengaruhi) dan dependen (dipengaruhi). Dengan kata lain, desain kausal bertujuan untuk menganalisa bagaimana suatu variabel mengpengaruhi variabel yang lainnya. Identifikasi variabel variabel yang digunakan dalam penelitian ini dikelompokkan menjadi dua yaitu variabel independen dan variabel dependen. Variabel independent yaitu tingkat perputaran kas $\left(\mathrm{X}_{1}\right)$, perputaran piutang $\left(\mathrm{X}_{2}\right)$, jumlah nasabah kredit $\left(\mathrm{X}_{3}\right)$. Sedangkan Variabel dependen yaitu ROA (Y). Sugiyono (2013) menyatakan, langkah-langkah penelitian kuantitatif yaitu sebagai berikut: (1) merumuskan masalah, (2) landasan teori, (3) merumuskan hipotesis, (4) melakukan penelitian, (5) mengumpulkan data dan menganalisis data, (6) menyusun laporan dan menyimpulkan.

Subjek dalam penelitian ini adalah LPD pada Kecamatan Kubu. Sedangkan objek dalam penelitian ini adalah tingkat perputaran kas , perputaran piutang, jumlah nasabah kredit dan ROA. Populasi dalam penelitian ini adalah LPD pada Kecamatan Kubu yang menyampaikan laporan tahuan periode 2019 sebanyak 30 LPD yang terdaftar pada Lembaga Pemberdayaan Lembaga Perkreditan Desa (LPLPD) di Kabupaten Karangasem.

Metode pengumpulan data yang digunakan dalam penelitian ini adalah pencatatan dokumen. Teknik analisis data yang digunakan dalam penelitian ini adalah analisis regresi linier berganda dengan bantuan program Statistical Package For Social Science (SPSS) versi 20 for Windows. Sebelum data dianalisis menggunakan analisis regresi linier berganda, terlebih dahulu diuji menggunakan uji asumsi klasik. Uji asumsi klasik adalah uji yang harus 
dilewati pertama kali agar keakuratan data tercapai. Uji asumsi klasik terdiri dari: (1) Uji Normalitas, (2) Uji Multikolinearitas, (3) Uji Heteroskedastisitas dan (4) Uji Autokorelasi

\section{Hasil dan Pembahasan}

Analisis Regresi Linier Berganda

Adapun hasil pengujian hipotesis dengan menggunkan analisis linier berganda pada struktur hubungan perputaran kas dan perputaran piutang serta jumlah nasabah kredit terhadap return on asset Lembaga perkreditan desa di kecamatan Kubu tahun 2019 dapat dilihat pada Gambar 1.

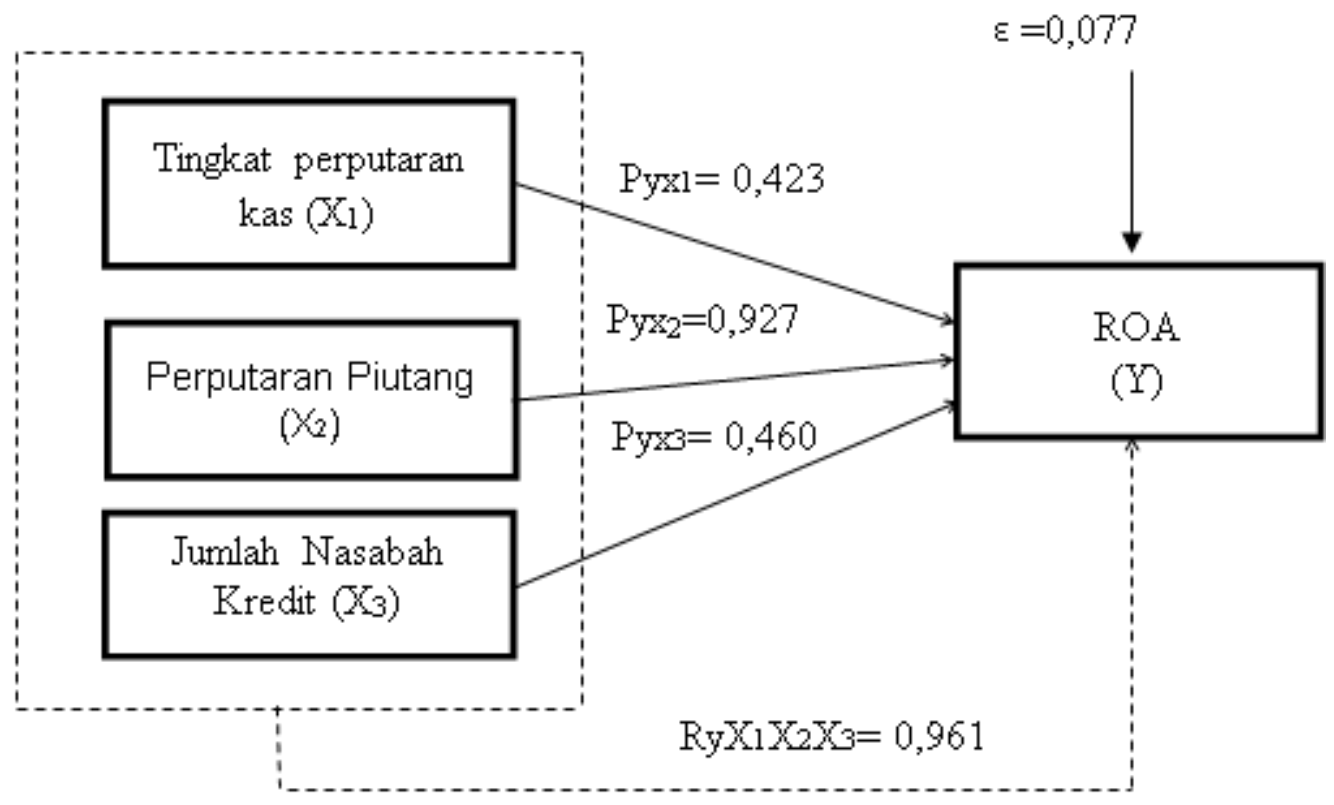

Gambar 1. Struktur Hubungan Perputaran kas $\left(\mathrm{X}_{1}\right)$, Perputaran Piutang $\left(\mathrm{X}_{2}\right)$ dan Jumlah Nasabah Kredit $\left(\mathrm{X}_{3}\right)$ terhadap Return On Asset $(\mathrm{Y})$

Hipotesis penelitian pertama "Ada pengaruh simultan dari perputaran kas perputaran piutang dan jumlah nasabah kredit terhadap return on asset". Berdasarkan rekapan hasil uji regresi berganda menunjukan hasil $\mathrm{Ryx}_{1} \mathrm{x}_{2} \mathrm{x}_{3}=0,961$ dengan $\mathrm{p}$-value $0,000<$ alpha 0,05 , dengan demikian yang menyatakan bahwa menolak Ho dan Ha diterima. yang berarti ada pengaruh signifikan dari perputaran kas $\left(\mathrm{X}_{1}\right)$, perputaran piutang $\left(\mathrm{X}_{2}\right)$ dan jumlah nasabah kredit $\left(\mathrm{X}_{3}\right)$ terhadap return on asset $(\mathrm{Y})$, dilihat dari sumbangan pengaruh hanya sebesar 92,3\%. Hasil tersebut menunjukan bahwa hanya sebesar 92,3\% return on asset (Y) dipengaruhi oleh perputaran kas $\left(\mathrm{X}_{1}\right)$, perputaran piutang $\left(\mathrm{X}_{2}\right)$ dan jumlah nasabah kredit $\left(\mathrm{X}_{3}\right)$. Sedangkan pengaruh variabel lain di luar perputaran kas $\left(\mathrm{X}_{1}\right)$, perputaran piutang $\left(\mathrm{X}_{2}\right)$ dan jumlah nasabah kredit $\left(\mathrm{X}_{3}\right)$ adalah sebesar 7,7\%.

Hipotesis penelitian kedua "Ada pengaruh dari perputaran kas terhadap return on asset" Berdasarkan rekapan hasil uji regresi berganda menunjukan hasil Pyx ${ }_{1}=0,423$ dengan p-value $0,025<0,05$, nilai signifikansi ini lebih kecil dari pada ROA 0,05, maka menolak $\mathrm{H}_{0}$. Sehingga dapat disimpulkan bahwa variabel perputaran kas $\left(\mathrm{X}_{1}\right)$ memiliki kontribusi terhadap return on asset $(\mathrm{Y})$. Nilai t positif menunjukkan bahwa variabel perputaran kas $\left(\mathrm{X}_{1}\right)$ mempunyai hubungan yang searah dengan return on asset (Y). Jadi dapat disimpulkan variabel perputaran kas $\left(\mathrm{X}_{1}\right)$ memiliki pengaruh positif signifikan terhadap return on asset (Y), dengan sumbangan pengaruh sebesar 17,89\%. Hal ini dapat disimpukan bahwa variabel perputaran kas secara parsial berperan dalam meningkatkan return on asset. Sehingga hipotesis kedua dalam penelitian ini diterima. 
Hipotesis penelitian ketiga "Ada pengaruh dari perputaran piutang terhadap return on asset". Berdasarkan rekapan hasil uji regresi berganda menunjukan hasil $\mathrm{Pyx}_{2}=0,927$ dengan p-value $0,000<0,05$, yang menyatakan bahwa menolak Ho yang berarti ada pengaruh positif dan signifikan dari perputaran piutang $\left(\mathrm{X}_{2}\right)$ terhadap return on asset $(\mathrm{Y})$, dengan sumbangan pengaruh sebesar $85,93 \%$. Hal ini dapat disimpukan bahwa variabel perputaran piutang secara parsial berperan dalam meningkatkan return on asset. Sehingga hipotesis ketiga penelitian ini diterima.

Hipotesis penelitian keempat "Ada pengaruh dari jumlah nasabah kredit terhadap return on asset". Berdasarkan rekapan hasil uji regresi berganda menunjukan hasil Pyx $3=$ 0,460 dengan p-value $0,014<0,05$, yang menyatakan bahwa menolak Ho yang berarti ada pengaruh positif dan signifikan dari jumlah nasabah kredit $\left(\mathrm{X}_{3}\right)$ terhadap return on asset $(\mathrm{Y})$, dengan sumbangan pengaruh sebesar $21,16 \%$. Hal ini dapat disimpukan bahwa variabel jumlah nasabah kredit secara parsial berperan dalam meningkatkan return on asset. Sehingga hipotesis keempat penelitian ini diterima.

Hasil penelitian ini menunjukkan bahwa secara simultan variabel perputaran kas, perputaran piutang, dan jumlah nasabah kredit secara signifikan berperan dalam meningkatkan return on asset (ROA). Tingkat perputaran kas dan perputaran piutang digunakan untuk menilai kemampuan LPD dalam mengelola kas dan piutang secara efisien. Tingkat perputaran kas menunjukkan kecepatan perubahan kembali aktiva lancar menjadi kas melalui penjualan. Tingkat perputaran piutang menunjukkan kecepatan pelunasan piutang menjadi kas kembali. Sementara jumlah nasabah kredit juga berperan penting dalam dalam meningkatkan laba suatu LPD karena apabila dalam suatu LPD jumlah nasabahnya meningkat maka akan memperoleh keuntungan yang meningkat pula. Keuntungan tersebut diperoleh dari bunga pinjaman yang diberikan oleh nasabah kredit. Pertumbuhan jumlah nasabah kredit akan berpengaruh pada ROA dari LPD tersebut. Hasil ini sejalan dengan teori Mulyadi (2005) menyatakan, apabila tingkat perputaran kasnya semakin meningkat, tingkat perputaran piutangnya juga semakin tinggi dan jumlah nasabah kreditnya terus bertambah, maka akan berbanding lurus dengan ROA pada perusahaan tersebut. Pernyataan tersebut didukung juga teori oleh Kasmir (2005) yang menyatakan, jika semakin tinggi perputaran kas, perputaran piutang dan jumlah nasabah yang terus meningkat maka akan meningkatkan keuntungan dari perusahaan tersebut. Pernyataan ini juga didukung oleh peneliatan yang dilakukan Putra dan Wirajaya (2013), bahwa tingkat perputaran kas dan perputaran piuang serta jumlah nasabah kredit berpengaruh positif terhadap profitabilitas (ROA) di Kecamatan Ubud.

Hasil penelitian ini menunjukkan ada pengaruh positif dan signifikan perputaran kas terhadap return on asset (ROA) LPD pada Kecamatan Kubu tahun 2019. Perputaran kas (cash turnover) adalah beberapa kali uang kas berputar dalam suatu tertentu melalui penjualan. Dengan menghitung perputaran kas akan diketahui sampai berapa jauh tingkat efisiensi yang dapat dicapai perusahaan dalam upaya mendayagunakan persediaan kas yang ada untuk mewujudkan tujuan perusahaan. Perputaran kas yang semakin tinggi akan semakin membaik, karena menunjukkan semakin efisiensi dalam penggunaan kas. Apabila perputaran kas yang berlebihan sedangkan modal kerja yang tersedia terlalu kecil maka akan kurang cukup untuk memenuhi kebutuhan perusahaan. Demikian pula sebaliknya, dengan makin rendahnya perputaran kas mengakibatkan banyaknya uang kas yang tidak produktif sehingga akan mengurangi ROA perusahaan. Kasmir (2012) menyatakan, rasio perputaran kas yaitu rasio yang berfungsi untuk mengukur tingkat kecukupan modal kerja perusahaan yang dibutuhkan untuk membayar tagihan dan membiayai penjualan. jika rasio perputaran ini tinggi perusahaan akan mampu mengelola kasnya sehingga akan mampu membayar kewajibannya. Pernyataan ini mendukung penelitian yang dilakukan oleh Friskayanti dkk 
(2014), dimana tingkat perputaran kas berpengaruh positif dan signifikan terhadap profitabilitas (ROA). Hal ini berarti apabila tingkat perputaran kas meningkat, maka ROA yang diterima oleh LPD juga akan meningkat. Namun sebaliknya, apabila tingkat perputaran kas menurun, maka ROA LPD juga akan menurun.

Hasil penelitian ini menunjukkan ada pengaruh positif dan signifikan perputaran piutang terhadap return on asset (ROA) LPD pada kecamatan Kubu tahun 2019. Piutang terjadi karena adanya penjualan secara kredit. Pemberian kredit kepada pembeli barang atau jasa umumnya dilakukan untuk memperbesar penjualan. Peningkatan penjualan dapat meningkatkan ROA perusahaan. Tapi disisi lain, peningkatan piutang juga membutuhkan tambahan pembiayaan, biaya untuk analisis kredit dan penagihan piutang, serta kemungkinan piutang yang macet tak dapat tertagih. Tinggi rendahnya receivable turnover mempunyai efek yang langsung terhadap besar kecilnya modal yang diinvestasikan dalam piutang. Makin tinggi turnover, berarti makin cepat perputarannya, yang berarti makin pendek waktu terikatnya modal dalam piutang, sehingga mempertahankan penjualan bersih tertentu, dengan naiknya turnover, dibutuhkan jumlah modal yang lebih kecil yang diinvestasikan dalam piutang. Menurut Munawir (2004), semakin tinggi rasio piutang (turn over) menunjukkan modal yang tertanam dalam piutang semakin rendah, sebalikanya kalau rasio semakin rendah berarti ada over investment dalam piutang sehingga memerlukan analisis lebih lanjut, mungkin karena bagian kredit dan penagihan bekerja tidak efektif atau mungkin ada perubahan dalam kebijakan pemberian kredit. Pernyataan ini mendukung oleh penelitian yang dilakukan oleh Friskayanti dkk (2014), bahwa tingkat perputaran piutang bepengaruh positif dan signifikan terhadap profitabilitas (ROA).

Hasil penelitian ini menunjukkan ada pengaruh positif dan signifikan jumlah nasabah kredit terhadap return on asset (ROA) LPD pada kecamatan Kubu tahun 2019. Nasabah adalah sumber pendapatan utama dalam LPD, yang dimana pendapatan itu diperoleh dari transaksi yang dilakukan oleh nasabahnya. Secara logika dapat kita ketahui apabila dalam suatu LPD jumlah nasabahnya meningkat maka akan memperoleh keuntungan yang meningkat. Keuntungan tersebut diperoleh dari bunga pinjaman yang diberikan kepada nasabah kredit. Hal itu dikarenakan nasabah merupakan peran penting dalam menjaga kelangsungan usaha LPD dalam mencari keuntungan. Sehingga tanpa adanya nasabah tidak akan ada perkembangan dalam suatu LPD tersebut. Jumlah nasabah kredit akan berpengaruh pada tingkat ROA suatu LPD tersebut. Pernyataan tersebut didukung juga oleh Riyanto (2001) menyatakan, meningkatnya jumlah nasabah memberikan laba yang cukup besar pada pertumbuhan LPD. Semakin banyak jumlah nasabah yang dimiliki oleh LPD, maka semakin besar pula kesempatan untuk memperbesar laba LPD. Hal itu di karenakan nasabah merupakan peran penting dalam menjaga kelangsungan usaha LPD dalam mencari keuntungan. Pernyataan ini mendukung oleh penelitian yang dilakukan oleh Dewi dan Ratnadi (2018),dimana jumlah nasabah kredit berpengaruh positif terhadap profitabilitas (ROA).

\section{Simpulan dan Saran}

Berdasarkan hasil penelitian dan dari pembahasan tersebut, maka dapat diperoleh simpulan sebagai berikut 1) Tingkat perputaran kas, perputaran piutang dan jumlah nasabah kredit berpengaruh signifikan terhadap return on assets pada LPD Kecamatan Kubu Tahun 2019, 2) Tingkat perputaran kas berpengaruh positif dan signifikan terhadap return on assets pada LPD Kecamatan Kubu Tahun 2019, 3) Perputaran piutang berpengaruh positif dan signifikan terhadap return on assets pada LPD Kecamatan Kubu Tahun 2019, 4) Jumlah nasabah kredit berpengaruh positif dan signifikan terhadap return on assets pada LPD Kecamatan Kubu Tahun 2019. 
Berdasarkan hasil penelitian, pembahasan dan simpulan yang telah dikemukakan tersebut, maka dapat diajukan beberapa saran sebagai berikut 1) Bagi pihak LPD pada Kecamatan Kubu, diharapkan agar lebih memperhatikan pengelolaan tingkat perputaran kas yang efisien, pengelolaan perputaran piutang yang harus optimal dan pihak LPD juga harus lebih selektif dalam mencairkan kreditnya. Karena, hal ini akan berdampak pada operasional serta pendapatan yang akan diperoleh LPD tersebut. Hal ini dapat dilakukan dengan cara pihak LPD meningkatkan pengawasan atau kontrol terhadap sistem administrasi, pelaksanaan pencairan kredit dan informasi kredit. Selain itu, dengan meningkatkan kemampuan SDM LPD dalam menganalisis kredit. Salah satunya yaitu dengan memberikan pelatihan 5C dan 7P, serta melakukan pemantauan penggunaan tersebut. Demi peningkatkan return on assets dan menjamin keberlangsungan LPD kedepannya, 2) Bagi peneliti selanjunya yang tertarik untuk mengkaji aspek yang serupa yaitu tingkat perputaran kas, perputaran piutang dan jumlah nasabah kredit terhadap return on assets diharapkan untuk mengembangkan penelitian ini dengan menggunakan subjek penelitian yang lebih luas, serta menambah jumlah populasi maupun sampel pada penelitiannya agar hasilnya dapat berdistribusi dengan baik dan juga dapat menambah aspek lain yang dapat mempengaruhi return on assets tersebut.

\section{Daftar Pustaka}

Dewi, N.L.P.S. dan Ratnadi, N.M.D. 2018." Pengaruh Jumlah Nasabah Kredit dan Kredit yang disalurkan pada Profitabilitas dengan NPL Sebagai Pemoderesasi" E-jurnal Akuntansi Universitas Udayana. Vol 22, No 1. , ISSN :2302-8556.

Friskayanti, M. E., Atmadja, A. W. T., \& Musmini, L. S. 2014. Pengaruh Tingkat Perputaran Kas, Peputaran Kredit, Biaya Operasional Pendapatan Operasional (BOPO), Kecukupan Modal dan Jumlah Nasabah Terhadap Profitabilitas ( Studi Pada LPD Kabupaten Buleleng Yang Terdaftar Pada LPLPD Periode 2009-2013 ). E-Journal S1 Ak Universitas Pendidikan Ganesha Jurusan Akuntansi S1, 2(1).

Hery. 2015. Analisis Laporan Keuangan Pendekatan Rasio Keuangan. Cetakan 1. Yogyakarta : Center For Academic Publihing Service (CAPS).

Kasmir. 2005. Etika Costumer Service. Jakarta: Raja Grafindo Persada.

Kasmir. 2012. Analisis Laporan Keuangan. cetakan ke lima, Jakarta: PT. Raja Grafindo Persada.

Mulyadi. 2005. Akuntansi Biaya. Edisi ke- 5. Yogyakarta: Akademi Manajemen Perusahaan YKPN.

Munawir. 2004. Analisa Laporan Keuangan. Edisi empat. Yogyakarta: Liberty.

Noviana, Yuli. Herawati, T.H, Sulindawati, N. L. G. E. 2015.” Pengaruh tingkat perputaran modal kerja, perputaran kas, perputaran piutang, pertumbuhan jumlah nasabah, dan jumlah karyawan terhadap profitabilitas koperasi simpan pinjam (KSP) di Kabupaten Buleleng”. E-Jurnal SI Akuntansi Universitas Pendidikan Ganesha. Volume 3, No 1.

Pratama, I Putu Wendra. 2019 “ Pengaruh Tingkat Perputaran Kas, Perputaran Piutang Dan Jumlah Nasabah Kredit Terhadap Profitabilitas Pada Lpd Kecamatan Negara”. Skripsi, 
Pengaruh Perputaran Kas dan Perputaran Piutang serta Jumlah Nasabah Terhadap Return On Assets pada Lembaga Perkreditan Desa di Kecamatan Kubu

Fakultas Ekonomi, Manajemen, Universitas Pendidikan Ganesha, Singaraja.

Putra.I.W.S, Wirajaya.I.G.A. 2013. "Pengaruh Tingkat Perputaran Kas Piutang dan Jumlah Nasabah Kredit pada Profitabilitas LPD di Kecamatan Ubud".E-jurnal Akuntasi Universitas Udayan, Vol. 3, No. 1, ISSN: 2302 -8556.

Rai, Rustina. 2003. Faktor-faktor yang Mempengaruhi Keberhasilan Lembaga Perkreditan Desa (LPD) di Kabupaten Tabanan. Buletin Studi Ekonomi Universitas Udayana, Denpasar.

Riyanto, Bambang. 2001. Dasar-dasar Pembelanjaan Perusahaan. Edisi keempat. Yogyakarta: BPFE.

Riyanto, Bambang 2011. Dasar-dasar Pembelanjaan Perusahaan. Edisi keempat. Yogyakarta: BPFE.

Sugiyono. 2012. Metode Penelitian Kuantitatif Kualitatif dan R\&D. Bandung: CV. Alfabeta.

Surata, I Nyoman. 2011. Penerapan Sanksi Adat oleh Desa Pakraman dalam Pengelolaan Lembaga Perkreditan Desa (LPD). Widyatech Jurnal Sains Dan Teknologi, Vol. 1, No. 1.

Wild, Subrahanyam and Halsey, R.F. 2007. Financial Statement Analysis. 9th ED. irwin USA : McGraw-Hill. 